\title{
Synthesis and characterization of six-membered pincer nickelacycles and application in alkylation of benzothiazole ${ }^{\dagger}$
}

\author{
HANUMANPRASAD PANDIRI ${ }^{\mathrm{a}}$, DIPESH M SHARMA ${ }^{\mathrm{a}}$, RAJESH G GONNADE ${ }^{\mathrm{b}}$ \\ and BENUDHAR PUNJI ${ }^{a, *}$ (D) \\ ${ }^{a}$ Organometallic Synthesis and Catalysis Group, Chemical Engineering Division, CSIR-National Chemical \\ Laboratory (CSIR-NCL), Dr. Homi Bhabha Road, Pune 411 008, Maharashtra, India \\ ${ }^{\mathrm{b}}$ Centre for Material Characterization, CSIR-National Chemical Laboratory (CSIR-NCL), Dr. Homi Bhabha \\ Road, Pune 411 008, Maharashtra, India \\ E-mail: b.punji@ncl.res.in
}

MS received 30 May 2017; revised 4 July 2017; accepted 5 July 2017

\begin{abstract}
Six-membered pincer nickelacycle complexes have been synthesized and employed for the catalytic $\mathrm{C}-\mathrm{H}$ bond alkylation of benzothiazole. The pincer nickelacycle, $\left\{\kappa^{\mathrm{P}}, \kappa^{\mathrm{C}}, \kappa^{\mathrm{P}}-\left(2{ }^{i}{ }^{i}{ }_{2}\right.\right.$ $\left.\left.\mathrm{POCH}_{2}-\mathrm{C}_{6} \mathrm{H}_{3}-6-\mathrm{CH}_{2} \mathrm{OP}^{i} \mathrm{Pr}_{2}\right)\right\} \mathrm{NiBr}$, $\left[\left({ }^{i} \mathrm{Pr}_{4}-\mathrm{POCCCOP}\right) \mathrm{NiBr}\right.$ (2)] was synthesized by the reaction of $1,3-{ }^{i} \mathrm{Pr}_{2} \mathrm{POCH}_{2}-\mathrm{C}_{6} \mathrm{H}_{4}-\mathrm{CH}_{2} \mathrm{OP}^{i} \mathrm{Pr}_{2}\left[\left({ }^{i} \mathrm{Pr}_{4}-\mathrm{POCCCOP}\right)-\mathrm{H}(\mathbf{1})\right]$ with $\left(\mathrm{CH}_{3} \mathrm{CN}\right)_{2} \mathrm{NiBr}_{2}$ in the presence of $\mathrm{Et}_{3} \mathrm{~N}$ via the $\mathrm{C}(2)-\mathrm{H}$ activation on ligand $\mathbf{1}$. Treatment of $\left[\left({ }^{i} \mathrm{Pr}_{4}-\mathrm{POCCCOP}\right) \mathrm{NiBr}\right](\mathbf{2})$ with $\mathrm{AgOAc}$ afforded the complex [ $\left.\left({ }^{i} \mathrm{Pr}_{4}-\mathrm{POCCCOP}\right) \mathrm{Ni}(\mathrm{OAc})\right]$ (3) in good yield. Both the complexes $\mathbf{2}$ and $\mathbf{3}$ were characterized by ${ }^{1} \mathrm{H}$, ${ }^{13} \mathrm{C}$ and ${ }^{31} \mathrm{P}-\mathrm{NMR}$ spectral analysis. Further, the molecular structures of complexes $\mathbf{2}$ and $\mathbf{3}$ were established by X-ray crystallography. The complex 2 was found to be an active catalyst for the $\mathrm{C}-\mathrm{H}$ bond alkylation of benzothiazole with alkyl halides containing $\beta$-hydrogen atoms.
\end{abstract}

Keywords. Pincer complex; six-membered nickelacycle; benzothiazole; C-H activation; alkylation.

\section{Introduction}

Pincer-based transition-metal complexes have attracted considerable attention because of their applications in diverse catalytic transformations and advanced materials. ${ }^{1}$ The tridentate coplanar coordination of the pincer ligands to the transition metals largely provides strong metal-ligand bonds and robust structures, which contribute to the thermal, air and moisture stability of the pincer complexes. ${ }^{2}$ The pincer nickel complexes based on bis(phosphine) [1,3- $\left(\mathrm{R}_{2} \mathrm{PCH}_{2}\right)_{2} \mathrm{C}_{6} \mathrm{H}_{4}$; (PCP)$\mathrm{H}]$ and bis(amine) $\left[1,3-\left(\mathrm{R}_{2} \mathrm{NCH}_{2}\right)_{2} \mathrm{C}_{6} \mathrm{H}_{4}\right.$; $\left.(\mathrm{NCN})-\mathrm{H}\right]$ ligands were among the early reports demonstrated by Shaw $^{3}$ and van Koten, ${ }^{4}$ respectively. Particularly, the $\mathrm{PCP}_{-}{ }^{5}$ and $\mathrm{NCN}^{6}$-type pincer nickel complexes have been most extensively studied, which led to the discoveries of diverse applications. In the last two decades, a number of new pincer nickel complexes based on

\footnotetext{
*For correspondence

${ }^{\dagger}$ Dedicated to Professor K. C. Kumara Swamy on the occasion of his 60th birth anniversary.
}

electronically distinct ligand systems, such as POCOP, ${ }^{7}$ $\mathrm{POCN},{ }^{8} \mathrm{PNP},{ }^{9} \mathrm{NNN},{ }^{10} \mathrm{PC}_{\mathrm{sp} 3} \mathrm{P},{ }^{11} \mathrm{POC}_{\mathrm{sp} 3} \mathrm{OP}^{5 \mathrm{f}, 7 \mathrm{~b}, 12}$ were developed (Chart 1). In this context, the groups of Guan and Zargarian have reported the reactivity and catalytic activity of (POCOP)NiX in a wide range of reactions. ${ }^{7 \mathrm{~d}, 13}$ Similarly, the unsymmetrical hybrid (POCN)NiX complexes have shown excellent activity for certain reactions compared to their symmetrical counterparts. ${ }^{8 f, g}$

In all the reported pincer nickel complexes, the ligating properties of the pincer ligand system were systematically tuned by changing the substituents on $\mathrm{PR}_{2}$ and $\mathrm{NR}_{2}(\mathrm{R}=$ alkyl, aryl $)$, and by changing the $\mathrm{PR}_{2}$-linker. These developments have underscored the importance of ligand tuning that has a direct impact on the reactivities of pincer nickel complexes. Notably, all the described pincer-nickels (nickelacycles) constitute two five-membered rings (Chart 1). Unfortunately, the impact of nickelacycle ring size on the reactivity and catalytic activity has rarely been examined on a pincer nickel complex. ${ }^{14}$ This could 
<smiles>[R2]Cc1cccc(CP)c1[N+]([R2])([R2])C</smiles>

(PCP)Ni

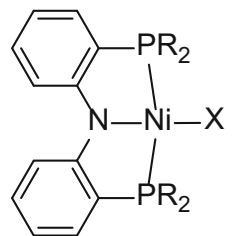

(PNP)Ni<smiles>[R20]Cc1cccc(CNC)c1[N+]([R2])[R]</smiles>

(NCN)Ni

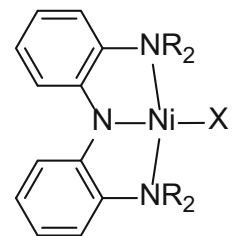

(NNN)Ni<smiles>[R7]CN([X])c1c(OP)cccc1OP</smiles>

(POCOP)Ni<smiles></smiles>

$\left(\mathrm{PC}_{\mathrm{sp} 3} \mathrm{P}\right) \mathrm{Ni}$<smiles>[R20]N1Cc2cccc(OP)c2C1([R20])[X]</smiles>

(POCN)Ni<smiles>[R2]N1COCC1COP</smiles>

(POC $_{\text {sp3 }}$ OP)Ni

Chart 1. Pincer nickel complexes.

be partially due to the difficulties in synthesizing higher ring size (six- or seven-membered) or lower ring size pincer nickel complexes, because of the low stability of such nickelacycles. Nevertheless, Jensen demonstrated the six-membered ring palladacycle as an excellent catalyst for the Heck coupling reaction compared to the five-membered palladacycle counterpart. ${ }^{15}$ Encouraged by the Jensen observation, and as a part of our activity on the development of pincer-based nickel complexes for the $\mathrm{C}-\mathrm{H}$ bond functionalization, ${ }^{10 \mathrm{~g}, 16}$ herein, we report the synthesis and structural characterization of six-membered nickelacycles $\left\{\kappa^{\mathrm{P}}, \kappa^{\mathrm{C}}, \kappa^{\mathrm{P}}-\left(2-{ }^{i} \mathrm{Pr}_{2} \mathrm{POCH}_{2}-\mathrm{C}_{6} \mathrm{H}_{3}-6-\mathrm{CH}_{2} \mathrm{OP}^{i} \mathrm{Pr}_{2}\right)\right\} \mathrm{NiX}$, $\left[\left({ }^{i} \mathrm{Pr}_{4}\right.\right.$-POCCCOP $\left.) \mathrm{NiX}\right]$, and demonstrate their catalytic activity for the alkylation of benzothiazole. Interestingly, various structural parameters of this phosphinitebased (POCCCOP)NiX complexes are distinct from both the phosphine-based (PCP)NiX and phosphinitebased (POCOP)NiX system, though they are much akin to the (PCP)NiX complex. The (POCCCOP)NiX complex acts as an active catalyst for the alkylation of benzothiazole with alkyl halides bearing $\beta$-hydrogen atoms.

\section{Experimental}

\subsection{Materials and physical measurements}

All manipulations were conducted under an argon atmosphere either in a glove box or using standard Schlenk techniques in pre-dried glasswares. The catalytic reactions were performed in flame-dried reaction vessels with Teflon screw cap. Solvents were dried over $\mathrm{Na} /$ benzophenone or $\mathrm{CaH}_{2}$ and distilled prior to use. Liquid reagents were flushed with argon before use. The ligand, 1,3- $\mathrm{C}_{6} \mathrm{H}_{4}-\left(\mathrm{CH}_{2}-\mathrm{O}-\mathrm{P}^{i} \mathrm{Pr}_{2}\right)_{2}$ $\left[\left({ }^{i} \mathrm{Pr}_{4}\right.\right.$-POCCCOP $\left.)-\mathrm{H}(\mathbf{1})\right]$ was synthesized according to previously described procedure. ${ }^{15}$ All other chemicals were obtained from commercial sources, and were used without further purification. Yields refer to the isolated compounds, estimated to be $>95 \%$ pure as determined by ${ }^{1} \mathrm{H}-\mathrm{NMR}$. High resolution mass spectrometry (HRMS) mass spectra were recorded on a Thermo Scientific Q-Exactive, Accela 1250 pump. Büchi 540 capillary melting point apparatus was used, and the reported values are uncorrected. NMR $\left({ }^{1} \mathrm{H},{ }^{13} \mathrm{C}\right.$ and $\left.{ }^{31} \mathrm{P}\right)$ spectra were recorded at $500 \mathrm{MHz}\left({ }^{1} \mathrm{H}\right), 125 \mathrm{MHz}\left\{{ }^{13} \mathrm{C}\right.$, DEPT (distortionless enhancement by polarization transfer) $\}$ and $202 \mathrm{MHz}\left({ }^{31} \mathrm{P}\right)$ on Bruker AV 500 spectrometers in $\mathrm{CDCl}_{3}$ or THF- $d_{8}$ solutions, if not otherwise specified; chemical shifts $(\delta)$ are given in ppm.

2.1a GC method: Gas Chromatography analyses were performed using a Shimadzu GC-2010 gas chromatograph equipped with a Shimadzu AOC-20s autosampler and a Restek RTX-5 capillary column $(30 \mathrm{~m}$ x $250 \mu \mathrm{m})$. The instrument was set to an injection volume of $1 \mu \mathrm{L}$, an inlet split ratio of 10:1, and inlet and detector temperatures of 250 and $320^{\circ} \mathrm{C}$, respectively. UHP-grade argon was used as carrier gas with a flow rate of $30 \mathrm{~mL} / \mathrm{min}$. The temperature program used for all the analyses is as follows: $80^{\circ} \mathrm{C}, 1 \mathrm{~min} ; 30^{\circ} \mathrm{C} / \mathrm{min}$ to $200^{\circ} \mathrm{C}$, $2 \mathrm{~min} ; 30^{\circ} \mathrm{C} / \mathrm{min}$ to $260^{\circ} \mathrm{C}, 3 \mathrm{~min} ; 30^{\circ} \mathrm{C} / \mathrm{min}$ to $300^{\circ} \mathrm{C}, 3 \mathrm{~min}$. Response factors for all the required compounds with respect to standard $n$-dodecane were calculated from the average of three independent $\mathrm{GC}$ runs.

\subsection{Synthesis of nickel complexes}

2.2a Synthesis of $\left({ }^{i} \mathrm{Pr}_{4}-\mathrm{POCCCOP}\right) \mathrm{NiBr}(2)$ : To the mixture of bisphosphinite, $1,3-\mathrm{C}_{6} \mathrm{H}_{4}\left(\mathrm{CH}_{2} \mathrm{OP}^{i} \mathrm{Pr}_{2}\right)_{2}(0.272$ $\mathrm{g}, 0.734 \mathrm{mmol})$ and $\left(\mathrm{CH}_{-3} \mathrm{CN}\right)_{2} \mathrm{NiBr}_{2}(0.221 \mathrm{~g}, 0.735 \mathrm{mmol})$ in a Schlenk flask were added toluene $(15 \mathrm{~mL})$ and $\mathrm{Et}_{3} \mathrm{~N}$ $(0.133 \mathrm{~mL}, 0.954 \mathrm{mmol})$. The resulted brown reaction mixture was stirred at $110^{\circ} \mathrm{C}$ for $3 \mathrm{~h}$. At ambient temperature, the volatiles were evaporated under vacuum and the product was 
extracted with pentane $(20 \mathrm{~mL}$ x 3$)$. Slow evaporation of the pentane solution at room temperature afforded the brownishyellow crystalline compound of $\left({ }^{i} \mathrm{Pr}_{4}\right.$-POCCCOP) $\mathrm{NiBr}(2)$. Yield: 0.230 g, $62 \%$. M.p.: $145^{\circ} \mathrm{C}(\mathrm{dec}) .{ }^{1} \mathrm{H}$ NMR $(500 \mathrm{MHz}$, $\left.\mathrm{CDCl}_{3}\right): \delta 6.95-6.84(\mathrm{~m}, 3 \mathrm{H}, \mathrm{Ar}-\mathrm{H}), 5.10$ (br s, $2 \mathrm{H}, \mathrm{CH}_{2}$ ), 4.86 (br s, $2 \mathrm{H}, \mathrm{CH}_{2}$ ), 3.04 (br s, 2H, CH), 1.91 (br s, $2 \mathrm{H}$, $\mathrm{CH}$ ), 1.50 (br s, 6H, $\mathrm{CH}_{3}$ ), 1.21 (br s, 12H, $\mathrm{CH}_{3}$ ), 0.41 (br s, $\left.6 \mathrm{H}, \mathrm{CH}_{3}\right) .{ }^{13} \mathrm{C}\left\{{ }^{1} \mathrm{H}\right\} \mathrm{NMR}\left(125 \mathrm{MHz}, \mathrm{CDCl}_{3}\right): \delta 144.4$ $\left(\mathrm{t}, J_{\mathrm{P}-\mathrm{C}}=26.7 \mathrm{~Hz}, \mathrm{C}_{\mathrm{q}}\right), 142.8\left(\mathrm{t}, J_{\mathrm{P}-\mathrm{C}}=6.2 \mathrm{~Hz}, 2 \mathrm{C}\right.$, $\left.\mathrm{C}_{\mathrm{q}}\right), 126.9(2 \mathrm{C}, \mathrm{CH}), 124.3(\mathrm{CH}), 78.9\left(2 \mathrm{C}, \mathrm{CH}_{2}\right), 27.5(4 \mathrm{C}$, $\mathrm{CH}), 18.1\left(6 \mathrm{C}, \mathrm{CH}_{3}\right), 15.9\left(2 \mathrm{C}, \mathrm{CH}_{3}\right) .{ }^{31} \mathrm{P}\left\{{ }^{1} \mathrm{H}\right\}$ NMR $(202$ $\mathrm{MHz}, \mathrm{CDCl}_{3}$ ): $\delta 141.6$ (s). HRMS (ESI): $\mathrm{m} / \mathrm{z}$ calcd. for $\left[\mathrm{C}_{20} \mathrm{H}_{35} \mathrm{O}_{2} \mathrm{P}_{2} \mathrm{BrNi}+\mathrm{H}\right]^{+}[\mathrm{M}+\mathrm{H}]^{+} 507.0722$ and 509.0701; found 507.1698 and 509.1648; $\left[\mathrm{C}_{20} \mathrm{H}_{35} \mathrm{O}_{2} \mathrm{P}_{2} \mathrm{BrNi}-\mathrm{Br}\right]^{+}$ $[\mathrm{M}-\mathrm{Br}]^{+}$427.1460, found 427.1462. Anal. Calcd. for $\mathrm{C}_{20} \mathrm{H}_{35} \mathrm{O}_{2} \mathrm{P}_{2} \mathrm{BrNi}$ : C, 47.28; H, 6.94\%. Found: C, 46.93; H, $6.77 \%$.

2.2b Synthesis of $\left({ }^{i} \mathrm{Pr}_{4}-\mathrm{POCCCOP}\right) \mathrm{Ni}(\mathrm{OAc})$ (3): To the solution of $\left({ }^{i} \mathrm{Pr}_{4}-\mathrm{POCCCOP}\right) \mathrm{NiBr}(2 ; 0.05 \mathrm{~g}, 0.098$ mmol) in THF (10 mL) was added AgOAc (0.0197 g, 0.118 mmol). The reaction mixture in Schlenk flask was covered with aluminium foil, and was stirred at room temperature for $3 \mathrm{~h}$. The reaction mixture was filtered through cannula filtration to remove the insoluble materials, and the filtrate was concentrated under vacuum to obtain nickel complex ( ${ }^{i} \mathrm{Pr}_{4}$-POCCCOP)Ni(OAc) (3) as brown crystalline solid. Yield: $0.032 \mathrm{~g}, 67 \% .{ }^{1} \mathrm{H}$ NMR $\left(500 \mathrm{MHz}, \mathrm{THF}-d_{8}\right): \delta 6.88-$ 6.76 (br s, 3H, Ar-H), 5.53-5.32 (m, 2H, $\mathrm{CH}_{2}$ ), 4.94-4.77 (m, 2H, $\mathrm{CH}_{2}$ ), 2.22 (br s, 2H, CH), 1.86 (br s, 2H, CH), 1.71 $\left(\mathrm{s}, 3 \mathrm{H}, \mathrm{OCH}_{3}\right), 1.42\left(\mathrm{~d}, J=5.7 \mathrm{~Hz}, 6 \mathrm{H}, \mathrm{CH}_{3}\right), 1.22-1.10$ $\left(\mathrm{m}, 12 \mathrm{H}, \mathrm{CH}_{3}\right), 0.40\left(\mathrm{~d}, J=5.7 \mathrm{~Hz}, 6 \mathrm{H}, \mathrm{CH}_{3}\right) .{ }^{13} \mathrm{C}\left\{{ }^{1} \mathrm{H}\right\}$ NMR (125 MHz, THF-d8): $\delta 176.5\left(\mathrm{C}_{\mathrm{q}}, \mathrm{COCH}_{3}\right), 144.4$ $\left(\mathrm{t}, J_{\mathrm{P}-\mathrm{C}}=6.2 \mathrm{~Hz}, 2 \mathrm{C}, \mathrm{C}_{\mathrm{q}}\right), 142.9\left(\mathrm{t}, J_{\mathrm{P}-\mathrm{C}}=29.1 \mathrm{~Hz}\right.$, $\left.\mathrm{C}_{\mathrm{q}}\right), 126.9(2 \mathrm{C}, \mathrm{CH}), 124.3(\mathrm{CH}), 79.0\left(2 \mathrm{C}, \mathrm{CH}_{2}\right), 28.2(\mathrm{t}$, $\left.J_{\mathrm{P}-\mathrm{C}}=13.4 \mathrm{~Hz}, 2 \mathrm{C}, \mathrm{CH}\right), 27.3\left(\mathrm{t}, J_{\mathrm{P}-\mathrm{C}}=9.5 \mathrm{~Hz}, 2 \mathrm{C}\right.$, $\mathrm{CH}), 24.3\left(\mathrm{CH}_{3}\right), 18.0\left(6 \mathrm{C}, \mathrm{CH}_{3}\right), 16.2\left(2 \mathrm{C}, \mathrm{CH}_{3}\right) .{ }^{31} \mathrm{P}\left\{{ }^{1} \mathrm{H}\right\}$ NMR (202 MHz, THF- $d_{8}$ ): $\delta 136.5$ (s). HRMS (ESI): $m / z$ calcd. for $\left[\mathrm{C}_{22} \mathrm{H}_{38} \mathrm{O}_{4} \mathrm{P}_{2} \mathrm{Ni}+\mathrm{H}\right]^{+}[\mathrm{M}+\mathrm{H}]^{+}$487.1672, found 487.0840; $\left[\mathrm{C}_{22} \mathrm{H}_{38} \mathrm{O}_{4} \mathrm{P}_{2} \mathrm{Ni}-\mathrm{OAc}\right]^{+}[\mathrm{M}-\mathrm{OAc}]^{+}$427.1460, found 427.1461 . This compound is highly moisture and thermal sensitive; hence, a satisfactory elemental analysis was not obtained.

\subsection{Representative procedure for alkylation reaction}

2.3a Synthesis of 2-n-octylbenzo[d]thiazole (6a): To a flame dried screw cap tube equipped with magnetic stirrer bar was introduced catalyst $2(0.006 \mathrm{~g}, 0.01 \mathrm{mmol}, 5.0$ $\mathrm{mol} \%)$, CuI (0.001 g, $0.005 \mathrm{mmol}, 2.5 \mathrm{~mol} \%), \mathrm{LiO}^{t} \mathrm{Bu}(0.032$ $\mathrm{g}, 0.4 \mathrm{mmol})$, benzothiazole $(4 ; 0.027 \mathrm{~g}, 0.2 \mathrm{mmol})$ and $1-$ iodooctane (5a; $0.096 \mathrm{~g}, 0.4 \mathrm{mmol}$ ) inside the glove box. To the above reaction mixture, 1,4-dioxane $(1.0 \mathrm{~mL})$ was added under an argon atmosphere, and the resultant reaction mixture was stirred at $100^{\circ} \mathrm{C}$ in a preheated oil bath for $24 \mathrm{~h}$. At ambient temperature, the reaction mixture was quenched with distilled water $(5 \mathrm{~mL})$ and neutralized with $2 \mathrm{~N} \mathrm{HCl}(0.5 \mathrm{~mL})$.
The crude product was then extracted with ethyl acetate (10 $\mathrm{mL} \times 3$ ) and the organic extract was dried over $\mathrm{Na}_{2} \mathrm{SO}_{4}$. Then, $n$-dodecane $(0.025 \mathrm{~mL}$, internal standard) was added and the mixture was stirred vigorously. An aliquot of the sample was withdrawn to a $\mathrm{GC}$ vial and subjected to the $\mathrm{GC}$ analysis. The yield of the coupled product $6 \mathbf{a}$ was found to be $91 \%$ (Note: The authenticity of all the coupled products was verified by comparing them with the isolated products). ${ }^{10 \mathrm{~g}}$

\section{$2.4 X$-ray crystallography}

Single crystal structures of compounds $\mathbf{2}$ and $\mathbf{3}$ were determined by measuring X-ray intensity data on a Bruker SMART APEX II single crystal X-ray CCD diffractometer having graphite-monochromatized (Mo-K $\alpha=0.71073 \AA$ ) radiation at room temperature $(296 \mathrm{~K}$ ) for $\mathbf{2}$ and at low temperature $(100 \mathrm{~K})$ for 3 . The X-ray generator was operated at $50 \mathrm{kV}$ and $30 \mathrm{~mA}$. A preliminary set of cell constants and an orientation matrix were calculated from total 36 frames. Data were collected with $\omega$ scan width of $0.5^{\circ}$ at eight different settings of $\varphi$ and $2 \theta$, keeping the sample-to-detector distance fixed at $5.00 \mathrm{~cm}$ for both the compounds. The X-ray data acquisition was monitored by the APEX2 program suit. ${ }^{17}$ All the data were corrected for Lorentz-polarization and absorption effects using SAINT and SADABS programs integrated into the APEX2 package. ${ }^{17}$ The structures were solved by direct methods and refined by full matrix least squares, based on $F^{2}$, using SHELX-97 ${ }^{18}$ integrated in the program suite APEX2. ${ }^{17}$ All the hydrogen atoms were placed in a geomerically idealized position and constrained to ride on their parent atoms. The ORTEP III ${ }^{19}$ view of both the compounds were drawn with $30 \%$ probability displacement ellipsoids and $\mathrm{H}$ atoms are not included for the clarity. Crystal data for the structures have been deposited in the Cambridge Crystallographic Data Center with numbers (compound numbers) CCDC-1546876 (2), CCDC-1546875 (3).

\section{Results and Discussion}

\subsection{Synthesis and characterization}

The $1,3-{ }^{i} \mathrm{Pr}_{2} \mathrm{POCH}_{2}-\mathrm{C}_{6} \mathrm{H}_{4}-\mathrm{CH}_{2} \mathrm{OP}^{i} \mathrm{Pr}_{2} \quad\left[\left({ }^{i} \mathrm{Pr}_{4}-\mathrm{POCCC}\right.\right.$ $\mathrm{OP})-\mathrm{H}$, (1)] ligand was prepared by following the literature procedure. ${ }^{15}$ Treatment of the pro-pincer ligand 1 with $\left(\mathrm{CH}_{3} \mathrm{CN}\right)_{2} \mathrm{NiBr}_{2}$ in the presence of triethylamine afforded the pincer complex, $\left\{\kappa^{\mathrm{P}}, \kappa^{\mathrm{C}}, \kappa^{\mathrm{P}}-\left(2-{ }^{i} \mathrm{Pr}_{2} \mathrm{POCH}_{2}\right.\right.$ $\left.\left.-\mathrm{C}_{6} \mathrm{H}_{3}-6-\mathrm{CH}_{2} \mathrm{OP}^{i} \mathrm{Pr}_{2}\right)\right\} \mathrm{NiBr}, \quad\left[\left({ }^{i} \mathrm{Pr}_{4}-\mathrm{POCCCOP}\right) \mathrm{NiBr}\right]$ (2) via the $\mathrm{C}(2)-\mathrm{H}$ bond activation on the ligand, $\left({ }^{i} \mathrm{Pr}_{4}\right.$-POCCCOP) $-\mathrm{H}$ (Scheme 1). The complex 2 was obtained as a brownish yellow solid. The ${ }^{31} \mathrm{P}$ NMR spectrum of complex 2 shows a single resonance at 141.6 ppm, which is $c a .14$ ppm more upfield shifted than the free ligand. In the ${ }^{1} \mathrm{H}$ NMR spectrum of 2 , the $-\mathrm{CH}_{2}$ protons show two broad singlets against a single set for all the four protons in free-ligand 1. Similarly, the 


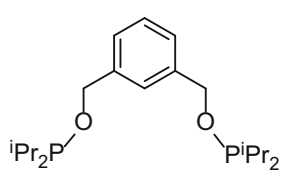

(1)

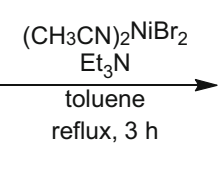

(2)

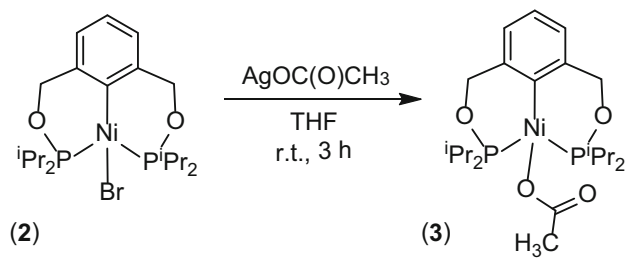

Scheme 1. Synthesis of $\left[\left({ }^{i} \mathrm{Pr}_{4}-\mathrm{POCCCOP}\right) \mathrm{NiX}\right]$ complexes.

four methylene $(-\mathrm{CH})$ protons displayed two broad singlets. The twenty four protons on eight methyl $\left(-\mathrm{CH}_{3}\right)$ groups displayed three sets of signals contrary to a single set in the ligand $\mathbf{1}$. The HRMS analysis of complex 2 shows a molecular mass peak $m / z$ 507.1698, which corresponds to the $[\mathbf{2}+\mathrm{H}]^{+}$ion. The molecular structure of complex $\mathbf{2}$ was further confirmed by the single crystal $\mathrm{X}$-ray diffraction study.

The acetate derivative of nickel complex was synthesized by the reaction of complex 2 with AgOAc in quantitative yield. Hence, the treatment of $\mathbf{2}$ with $\mathrm{AgOAc}$ in THF afforded the complex $\left\{\kappa^{\mathrm{P}}, \kappa^{\mathrm{C}}, \kappa^{\mathrm{P}}-\left(2{ }^{i} \mathrm{Pr}_{2} \mathrm{POCH}_{2}\right.\right.$ $\left.\left.-\mathrm{C}_{6} \mathrm{H}_{3}-6-\mathrm{CH}_{2} \mathrm{OP}^{i} \mathrm{Pr}_{2}\right)\right\} \mathrm{Ni}(\mathrm{OAc}), \quad\left[\left({ }^{i} \mathrm{Pr}_{4}\right.\right.$-POCCCOP $) \mathrm{Ni}$ $(\mathrm{OAc})$ ] (3) as a brown crystalline solid (Scheme 1). The complex 3 shows a single peak at $136.5 \mathrm{ppm}$ in the ${ }^{31} \mathrm{P}$ NMR spectrum. The ${ }^{1} \mathrm{H}$ NMR data of complex $\mathbf{3}$ is almost identical with that of $\mathbf{2}$, except the methyl protons on acetate $\left(-\mathrm{OC}(\mathrm{O}) \mathrm{CH}_{3}\right)$ displaying a singlet at $1.71 \mathrm{ppm}$. The mass spectrum of $\mathbf{3}$ displayed peaks at $\mathrm{m} / \mathrm{z} 487.0840$ and 427.1461 for the ions $[3+\mathrm{H}]^{+}$and $[3$ $-\mathrm{OAc}]^{+}$, respectively. The X-ray analysis further establishes the structure of compound $\mathbf{3}$.

\subsection{Structure of complexes}

The ORTEP diagrams of complexes $\mathbf{2}$ and $\mathbf{3}$ are shown in Figures 1 and 2, respectively. Selected bond lengths and bond angles are given in Table 1. The coordination geometry around the nickel center in both the complexes $\mathbf{2}$ and $\mathbf{3}$ is square planar. Both the Ni-P bond distances (2.1951(6) $\AA$ ) in $\mathbf{2}$ are exactly same and slightly longer than the corresponding bond distance in $\left(2,6-\left({ }^{i} \mathrm{Pr}_{2} \mathrm{PCH}_{2}\right)_{2} \mathrm{C}_{6} \mathrm{H}_{3}\right) \mathrm{NiBr}(2.1645(6) \AA)^{11 \mathrm{~b}}$ and $\left(2,6-\left({ }^{i} \mathrm{Pr}_{2} \mathrm{PO}\right){ }_{2} \mathrm{C}_{6} \mathrm{H}_{3}\right) \mathrm{NiBr}($ ca. 2.142-2.153 $\mathrm{\AA}) .{ }^{20}$ The Ni-C bond distance follows the same trend, being slightly longer in 2 (1.934(3) $\AA$ ) than the PCP- (ca. $1.918 \AA$ ) and POCOP-analogue (ca. $1.885 \AA$ ). The NiBr bond distance in 2 (2.3416(6) $\AA$ ) is comparable with that of PCP-analogue (ca. $2.344 \AA$ ), ${ }^{11 \mathrm{~b}}$ whereas it is slightly longer than that observed in POCOP-analogue (ca. $2.323 \AA) .{ }^{20}$ This can be attributed to the similar $\sigma$-donor strength of the ligands (POCCCOP) and PCP towards nickel in the respective nickel complexes. The nickel center in complex $\mathbf{2}$ forms a perfect square plane

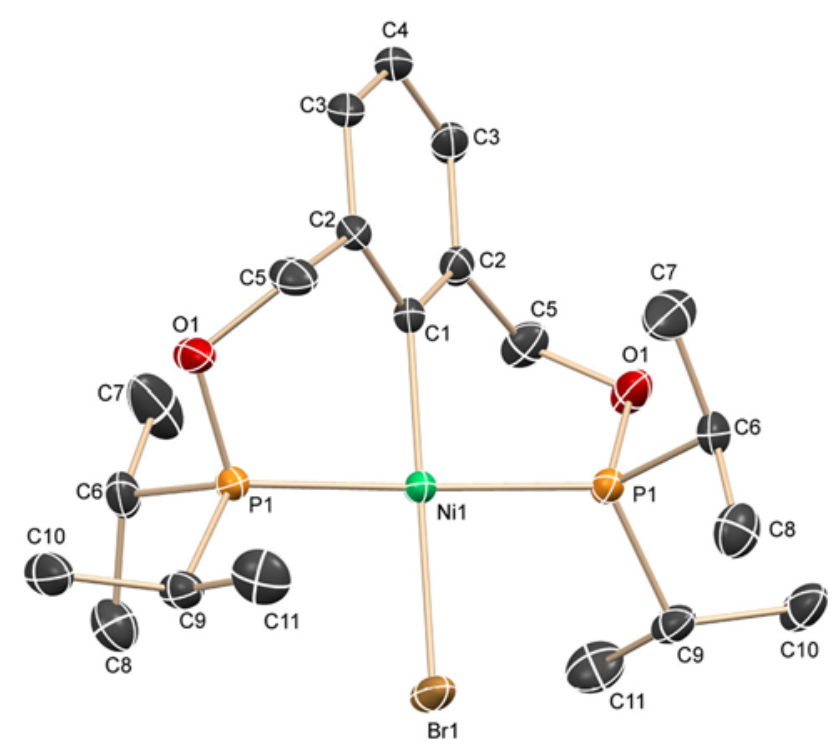

Figure 1. Thermal ellipsoid plot of $\left[\left({ }^{i} \mathrm{Pr}_{4}\right.\right.$-POCCCOP $)$ $\mathrm{NiBr}$ (2). All the hydrogen atoms are omitted for clarity.

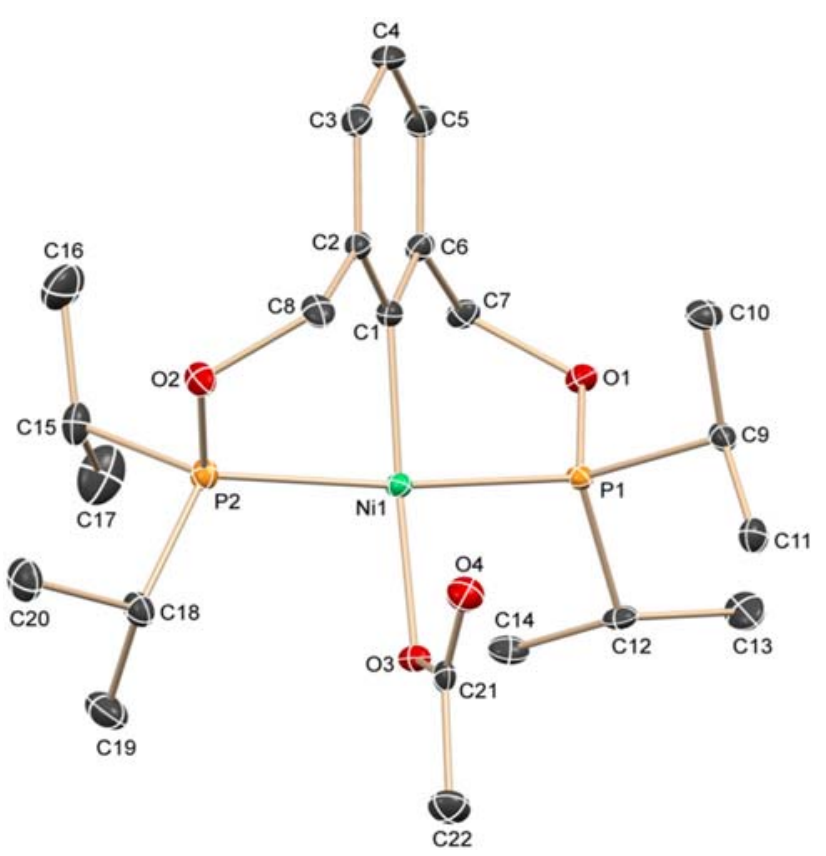

Figure 2. Thermal ellipsoid plot of $\left[\left({ }^{i} \mathrm{Pr}_{4}\right.\right.$-POCCCOP $)$ $\mathrm{Ni}(\mathrm{OAc})](3)$. All the hydrogen atoms are omitted for clarity. 
Table 1. Selected bond lengths $(\AA)$ and bond angles $\left(^{\circ}\right)$ of compounds $\mathbf{2}$ and $\mathbf{3}$.

\begin{tabular}{|c|c|c|c|c|c|}
\hline & \multicolumn{2}{|c|}{ Bond lengths ( } & & \multicolumn{2}{|c|}{ Bond angles $\left({ }^{\circ}\right)$} \\
\hline & 2 & 3 & & 2 & 3 \\
\hline $\mathrm{Ni}(1)-\mathrm{C}(1)$ & $1.934(3)$ & $1.910(3)$ & $\mathrm{C}(1)-\mathrm{Ni}(1)-\mathrm{O}(3)$ & - & $173.99(9)$ \\
\hline $\mathrm{Ni}(1)-\mathrm{O}(3)$ & - & $1.9445(17)$ & $\mathrm{C}(1)-\mathrm{Ni}(1)-\mathrm{P}(1)$ & $89.254(17)$ & $88.33(8)$ \\
\hline Ni(1)-P(1) & $2.1950(6)$ & $2.1774(7)$ & $\mathrm{C}(1)-\mathrm{Ni}(1)-\mathrm{P}(2)$ & $89.254(17)$ & $85.69(8)$ \\
\hline Ni(1)-P(2) & $2.1950(6)$ & $2.1955(7)$ & $\mathrm{C}(1)-\mathrm{Ni}(1)-\mathrm{Br}(1)$ & 180.0 & - \\
\hline \multirow[t]{5}{*}{$\mathrm{Ni}(1)-\mathrm{Br}(1)$} & $2.3416(6)$ & - & $\mathrm{P}(1)-\mathrm{Ni}(1)-\mathrm{O}(3)$ & - & $92.23(5)$ \\
\hline & & & $\mathrm{P}(2)-\mathrm{Ni}(1)-\mathrm{O}(3)$ & - & $94.48(5)$ \\
\hline & & & $\mathrm{P}(1)-\mathrm{Ni}(1)-\mathrm{Br}(1)$ & $90.746(17)$ & - \\
\hline & & & $\mathrm{P}(2)-\mathrm{Ni}(1)-\mathrm{Br}(1)$ & $90.746(17)$ & - \\
\hline & & & $\mathrm{P}(1)-\mathrm{Ni}(1)-\mathrm{P}(2)$ & $178.51(3)$ & $170.59(3)$ \\
\hline
\end{tabular}
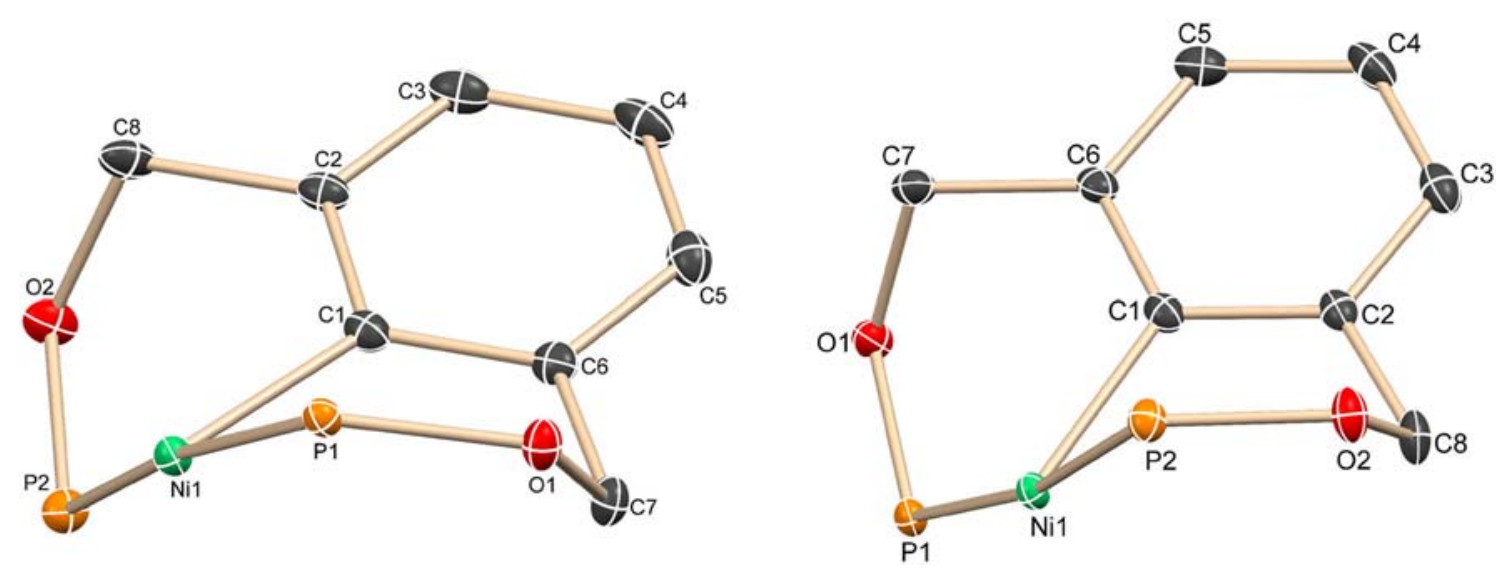

Figure 3. Thermal ellipsoid plot of $\left[\left({ }^{i} \mathrm{Pr}_{4}-\mathrm{POCCCOP}\right) \mathrm{NiBr}\right](\mathbf{2})$ showing two different nickelacycle cores.

with the cis angles $c a .89 .2$ and $90.7^{\circ}$ and the trans angles $c a .178 .5$ and $180.0^{\circ}$. The $\mathrm{P}-\mathrm{Ni}-\mathrm{P}$ bite angle of the POCCCOP ligand in complex $2\left(178.51(3)^{\circ}\right)$ is significantly larger than that in $\mathrm{PCP}$-analogue $\left(c a .170 .6^{\circ}\right)$ and POCOP-analogue $\left(\mathrm{ca} .164 .9^{\circ}\right)$. Similarly, the C$\mathrm{Ni}-\mathrm{P}$ bond angle in $2\left(89.254(17)^{\circ}\right)$ is larger than the corresponding bond angles in PCP-analogue ( $\left.c a .85 .3^{\circ}\right)$ and POCOP-analogue ( $\left.c a .82 .3,82.7^{\circ}\right)$. The comparison of all the bond lengths and bond angles of 2 with (PCP) NiBr and (POCOP)NiBr shows that the structural features of complex $\mathbf{2}$ are closer to the (PCP)NiBr than with the (POCOP)NiBr complex. This could be due to the electronic density provided by the (POCCCOP)moiety towards nickel in (POCCCOP)NiX is similar to that provided by (PCP)-moiety towards nickel in the complex (PCP)NiBr. The presence of methylene $\left(-\mathrm{CH}_{2}\right)$ group in the six-membered nickelacycle (POCCCOP)NiX might have a crucial role for this changes. The Ni-P and Ni-C bond lengths in complex $\mathbf{3}$ are comparable to that observed in complex 2 . However, the $\mathrm{P}-\mathrm{Ni}-\mathrm{P}$ bite angle in $\mathbf{3}\left(170.59(3)^{\circ}\right)$ is significantly shorter than the corresponding bond angle in $\mathbf{2}$. Both the six-membered nickelacycles containing $\mathrm{Ni}, \mathrm{P}, \mathrm{O}$ and $\mathrm{C}$ exist in a boat-like conformation, and they are anti to each other (Figure 3). This is the first solid-state structure for a six-membered pincer nickelacycle complex.

\section{$3.3 C-H$ bond alkylation of benzothiazole}

The $\mathrm{C}-\mathrm{H}$ bond functionalization of sulphur containing azoles, such as benzothiazole, is very crucial as they are ubiquitous building blocks of several pharmaceutical and biologically active compounds. ${ }^{21}$ Particularly, the alkylation of benzothiazole with alkyl halides containing $\beta$-hydrogens is a very important and challenging reaction, due to the undesired $\beta$ elimination from these electrophiles at the active metal center after the oxidative addition of the same. ${ }^{22}$ In this regards, the newly developed six-membered nickelacycle ( ${ }^{i} \mathrm{Pr}_{4}$-POCCCOP) $\mathrm{NiBr}$ (2) was screened and employed for the alkylation of benzothiazole (4) with alkyl halides (5) to obtain the alkylated products 6 (Scheme 2; see Supporting Information for details). Notably, the alkylation reaction of benzothiazole with various alkyl halides afforded better yields while employing six-membered nickelacycle $\left({ }^{i} \mathrm{Pr}_{4}\right.$-PO$\mathrm{CCCOP}) \mathrm{NiBr}(2)$ as a catalyst than with either $\left({ }^{i} \mathrm{Pr}_{4}\right.$ -PCP) NiBr or $\left({ }^{i} \mathrm{Pr}_{4}\right.$-POCOP)Ni(OAc) catalysts (Table 


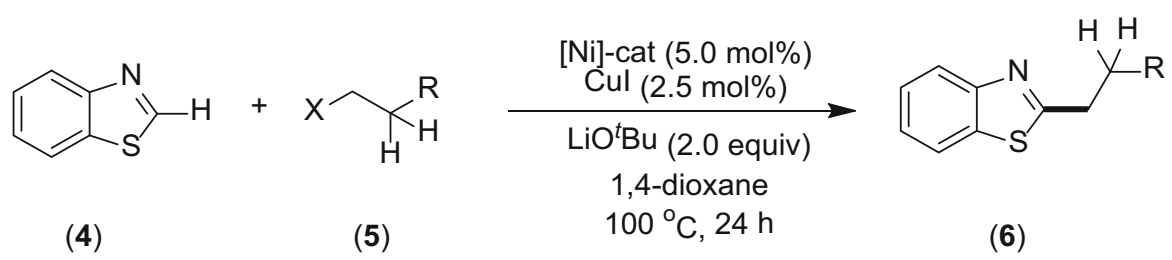

Scheme 2. Nickel-catalyzed alkylation of benzothiazole.

S1, Supporting Information). However, the catalyst 2 is slightly inferior than earlier reported catalyst systems for the same reaction. ${ }^{10 \mathrm{~g}, 23}$ This catalyst system requires further study to establish the actual activation path.

\section{Conclusions}

In summary, we have synthesized two six-membered pincer nickelacycle complexes and demonstrated their catalytic application for the alkylation of benzothiazole. Both the six-membered pincer nickelacycles, $\left[\left({ }^{i} \mathrm{Pr}_{4}\right.\right.$-POCCCOP $\left.) \mathrm{NiX} ;(\mathrm{X}=\mathrm{Br}, \mathrm{OAc})\right]$ were synthesized in good yields and structurally characterized. The electronic features of these bis(phosphinite)nickelacycles are very similar to the bis(phosphine), $\left({ }^{i} \mathrm{Pr}_{4}-\mathrm{PCP}\right) \mathrm{Ni}$ rather than the bis(phosphinite), $\left({ }^{i} \mathrm{Pr}_{4}\right.$ -POCOP)Ni complex. The complex, $\left({ }^{i} \mathrm{Pr}_{4}\right.$-POCCCOP) $\mathrm{NiBr}$ catalyzed the alkylation of benzothiazole with alkyl iodides. The $\mathrm{C}-\mathrm{H}$ alkylation by the six-membered nickelacycle $\left({ }^{i} \mathrm{Pr}_{4}-\mathrm{POCCCOP}\right) \mathrm{NiBr}$ is superior to the five-membered nickel complexes, $\left({ }^{i} \mathrm{Pr}_{4}-\mathrm{PCP}\right) \mathrm{NiBr}$ and $\left({ }^{i} \mathrm{Pr}_{4}\right.$-POCOP $) \mathrm{Ni}(\mathrm{OAc})$. Further utilization of these sixmembered pincer nickelacycles, $\left({ }^{i} \mathrm{Pr}_{4}\right.$-POCCCOP $) \mathrm{NiX}$ in other $\mathrm{C}-\mathrm{H}$ functionalization reactions is currently underway in our laboratory.

\section{Supplementary Information (SI)}

Crystallographic data for the structural analyses of complexes 2 and $\mathbf{3}$ have been deposited with the Cambridge Crystallographic Data Centre having CCDC Nos. 1546876 and 1546875 , respectively. Copy of this information is available on request at free of charge from CCDC, Union Road, Cambridge, CB21EZ, UK (e-mail: deposit@ccdc.ac.uk or http:// www.ccdc.cam.ac.uk). Crystal data and structure refinement, HRMS spectra and NMR spectra of complexes $\mathbf{2}$ and $\mathbf{3}$ and Table $\mathrm{S} 1$ are available at www.ias.ac.in/chemsci.

\section{Acknowledgements}

This work was financially supported by SERB, New Delhi, India (SR/S1/IC-42/2012). We are thankful to the Alexander von Humboldt Foundation, Germany for an equipment grant. H.P.P. and D.M.S thank CSIR, New Delhi for the research fellowship.

\section{References}

1. (a) Morales-Morales D and Jensen C M 2007 In The Chemistry of Pincer Compounds (Amsterdam: Elsevier); (b) Szabó K J and Wendt O F 2014 In Pincer and PincerType Complexes: Applications in Organic Synthesis and Catalysis (Weinheim: Wiley-VCH); (c) Albrecht M and van Koten G 2001 Platinum Group Organometallics Based on "Pincer" Complexes: Sensors, Switches, and Catalysts Angew. Chem. Int. Ed. 40 3750; (d) Singleton J $\mathrm{T} 2003$ The uses of pincer complexes in organic synthesis Tetrahedron 59 1837; (e) van der Vlugt J I and Reek J N H 2009 Neutral Tridentate PNP Ligands and Their Hybrid Analogues: Versatile Non-Innocent Scaffolds for Homogeneous Catalysis Angew. Chem. Int. Ed. 48 8832

2. van der Boom M E and Milstein D 2003 Cyclometalated Phosphine-Based Pincer Complexes: Mechanistic Insight in Catalysis, Coordination, and Bond Activation Chem. Rev. 1031759

3. Moulton C J and Shaw B L 1976 Transition metal-carbon bonds. Part XLII. Complexes of nickel, palladium, platinum, rhodium and iridium with the tridentate ligand 2,6-bis[(di-t- butylphosphino)methyl]phenyl J. Chem. Soc., Dalton Trans. 1020

4. (a) Grove D M, van Koten G, Zoet R, Murrall N W and Welch A J 1983 Unique stable organometallic nickel(III) complexes; syntheses and the molecular structure of $\left[\mathrm{Ni}\left[\mathrm{C}_{6} \mathrm{H}_{3}\left(\mathrm{CH}_{2} \mathrm{NMe}_{2}\right)_{2}-2,6\right] \mathrm{I}_{2}\right] \mathrm{J}$. Am. Chem. Soc. 105 1379; (b) Grove D M, van Koten G, Ubbels H J C, Zoet R and Spek A L 1984 Organonickel(II) complexes of the tridentate monoanionic ligand o,o'bis[(dimethylamino)methylphenyl (N-C-N). Syntheses and the X-ray crystal structure of the stable nickel(II) formate $\left[\mathrm{Ni}(\mathrm{N}-\mathrm{C}-\mathrm{N}) \mathrm{O}_{2} \mathrm{CH}\right]$ Organometallics 31003

5. (a) Cámpora J, Palma P, del Rio D, M C M and Álvarez E 2004 Synthesis and Reactivity of a Mononuclear Parent Amido Nickel Complex. Structures of $\mathrm{Ni}\left[\mathrm{C}_{6} \mathrm{H}_{3}-2,6-\left(\mathrm{CH}_{2} \mathrm{P}^{i} \mathrm{Pr}_{2}\right)_{2}\right]\left(\mathrm{NH}_{2}\right)$ and $\mathrm{Ni}\left[\mathrm{C}_{6} \mathrm{H}_{3}-2,6-\left(\mathrm{CH}_{2} \mathrm{P}^{i} \mathrm{Pr}_{2}\right)_{2}\right](\mathrm{OMe})$ Organometallics 23 5653; (b) Cámpora J, Palma P, del Rio D and Eleuterio Á 2004 CO Insertion Reactions into the $\mathrm{M}-\mathrm{OH}$ Bonds of Monomeric Nickel and Palladium Hydroxides. Reversible Decarbonylation of a Hydroxycarbonyl Palladium Complex Organometallics 23 1652; (c) Boro B J, Duesler E N, Goldberg K I and Kemp R A 2009 Synthesis, Characterization, and Reactivity of Nickel Hydride Complexes Containing 2,6- $\mathrm{C}_{6} \mathrm{H}_{3}\left(\mathrm{CH}_{2} \mathrm{PR}_{2}\right)_{2}\left(R={ }^{t} \mathrm{Bu}\right.$, ${ }^{c}$ Hex, and ${ }^{i} \mathrm{Pr}$ ) Pincer Ligands Inorg. Chem. 48 5081; (d) Schmeier T J, Hazari N, Incarvito C D and Raskatov J A 2011 Exploring the reactions of $\mathrm{CO}_{2}$ with PCP supported nickel complexes Chem. Commun. 47 1824; 
(e) Schmeier T J, Nova A, Hazari N and Maseras F 2012 Synthesis of PCP-Supported Nickel Complexes and their Reactivity with Carbon Dioxide Chem. - Eur. J. 18 6915; (f) Connelly S J, Zimmerman A C, Kaminsky W and Heinekey D M 2012 Synthesis, Structure, and Reactivity of a Nickel Dihydrogen Complex Chem. - Eur. J. 18 15932; (g) Yang Z, Liu D, Liu Y, Sugiya M, Imamoto T and Zhang W 2015 Synthesis and Structural Characterization of Nickel Complexes Possessing PStereogenic Pincer Scaffolds and Their Application in Asymmetric Aza-Michael Reactions Organometallics 341228

6. (a) Mitsudo K, Imura T, Yamaguchi $\mathrm{T}$ and Tanaka H 2008 Preparation of a cationic bisoxazolinic nickel pincer catalyst and its applications to Michael addition and Mizoroki-Heck reaction Tetrahedron Lett. 49 7287; (b) Shao D -D, Niu, J -L, Hao X -Q, Gong J -F and Song M -P 2011 Neutral and cationic chiral NCN pincer nickel(II) complexes with 1,3-bis(2'-imidazolinyl)benzenes: synthesis and characterization Dalton Trans. 40 9012; (c) Antonov A A, Samsonenko D G, Talsi E P and Bryliakov K P 2013 Formation of Cationic Intermediates upon the Activation of Bis(imino)pyridine Nickel Catalysts Organometallics 32 2187; (d) Cloutier J -P, Vabre B, Moungang-Soumé B and Zargarian D 2015 Synthesis and Reactivities of New NCN-Type Pincer Complexes of Nickel Organometallics 34 133; (e) Zargarian D, Castonguay A and Spasyuk D M 2013 ECE-Type Pincer Complexes of Nickel Top Organomet. Chem. 40131

7. (a) Gómez-Benítez V, Baldovino-Pantaleón O, HerreraÁlvarez C, Toscano R A and Morales-Morales D 2006 High yield thiolation of iodobenzene catalyzed by the phosphinite nickel PCP pincer complex: $\left[\mathrm{NiCl}\left\{\mathrm{C}_{6} \mathrm{H}_{3}-2,6-\left(\mathrm{OPPh}_{2}\right)_{2}\right\}\right]$ Tetrahedron Lett. 47 5059; (b) Pandarus V and Zargarian D 2007 New Pincer-Type Diphosphinito (POCOP) Complexes of Nickel Organometallics 26 4321; (c) Solano-Prado M A, Estudiante- Negrete F and Morales-Morales D 2010 Group 10 phosphinite POCOP pincer complexes derived from 4-n-dodecylresorcinol: An alternative way to produce non-symmetric pincer compounds Polyhedron 29 592; (d) Zhang J, Medley C M, Krause J A and Guan H 2010 Mechanistic Insights into C-S Cross-Coupling Reactions Catalyzed by Nickel Bis(phosphinite) Pincer Complexes Organometallics 29 6393; (e) Salah A B and Zargarian D 2011 The impact of P-substituents on the structures, spectroscopic properties, and reactivities of POCOP-type pincer complexes of nickel(II) Dalton Trans. 40 8977; (f) Lefèvre X, Durieux G, Lesturgez S and Zargarian D 2011 Addition of amines and phenols to acrylonitrile derivatives catalyzed by the POCOP-type pincer complex $\left[\left\{\kappa^{\mathrm{P}}, \kappa^{\mathrm{C}}, \kappa^{\mathrm{P}}-2,6-\left(\mathrm{i}-\mathrm{Pr}_{2} \mathrm{PO}\right)_{2} \mathrm{C}_{6} \mathrm{H}_{3}\right\} \mathrm{Ni}(\mathrm{NCMe})\right]\left[\mathrm{OSO}_{2}\right.$ $\mathrm{CF}_{3}$ ] J. Mol. Catal. A: Chem. 335 1; (g) Lefèvre X, Spasyuk D M and Zargarian D 2011 New POCOPtype pincer complexes of Nickel(II) J. Organomet. Chem. 696 864; (h) Xu G, Li X and Sun H 2011 Nickel-catalyzed cross- coupling of primary alkyl halides with phenylethynyl- and trimethylsilyethynyllithium reagents J. Organomet. Chem. 696 3011; (i) Vabre B, Spasyuk D M and Zargarian D 2012 Impact of Backbone Substituents on POCOP-Ni
Pincer Complexes: A Structural, Spectroscopic, and Electrochemical Study Organometallics 31 8561; (j) Estudiante- Negrete F, Hernández-Ortega $\mathrm{S}$ and Morales-Morales D 2012 Ni(II)-POCOP pincer compound $\left[\mathrm{NiCl}\left\{\mathrm{C}_{10} \mathrm{H}_{5}-2,10-\left(\mathrm{OPPh}_{2}\right)_{2}\right\}\right]$ an efficient and robust nickel catalyst for the Suzuki-Miyaura coupling reactions Inorg. Chim. Acta 387 58; (k) Ramakrishnan S, Chakraborty S, Brennessel W W, Chidsey C E D and Jones W D 2016 Rapid oxidative hydrogen evolution from a family of square-planar nickel hydride complexes Chem. Sci. 7 117; (1) Liu T, Meng W, Ma Q -Q, Zhang J, Li H, Li S, Zhao Q and Chen X 2017 Hydroboration of $\mathrm{CO}_{2}$ catalyzed by bis(phosphinite) pincer ligated nickel thiolate complexes Dalton Trans. 464504

8. (a) Gong J -F, Zhang $\mathrm{Y}-\mathrm{H}$, Song $\mathrm{M}-\mathrm{P}$ and $\mathrm{Xu}$ C 2007 New PCN and PCP Pincer Palladium(II) Complexes: Convenient Synthesis via Facile OnePot Phosphorylation/Palladation Reaction and Structural Characterization Organometallics 26 6487; (b) Spasyuk D M, Zargarian D and van der Est A 2009 New POCN-Type Pincer Complexes of Nickel(II) and Nickel(III) Organometallics 28 6531; (c) Niu J -L, Chen Q - T, Hao X -Q, Zhao Q -X, Gong J -F and Song M -P 2010 Diphenylprolinol-Derived Symmetrical and Unsymmetrical Chiral Pincer Palladium(II) and Nickel(II) Complexes: Synthesis via One-Pot Phosphorylation/Metalation Reaction and $\mathrm{C}-\mathrm{H}$ Activation Organometallics 29 2148; (d) Spasyuk D M, Gorelsky S I, van der Est A and Zargarian D 2011 Characterization of Divalent and Trivalent Species Generated in the Chemical and Electrochemical Oxidation of a Dimeric Pincer Complex of Nickel Inorg. Chem. 50 2661; (e) Yang M -J, Liu Y -J, Gong J -F and Song M -P 2011 Unsymmetrical Chiral PCN Pincer Palladium(II) and Nickel(II) Complexes with Aryl-Based Aminophosphine-Imidazoline Ligands: Synthesis via Aryl C-H Activation and Asymmetric Addition of Diarylphosphines to Enones Organometallics 303793 ; (f) Mougang-Soumé B, Belanger-Gariépy F and Zargarian D 2014 Synthesis, Characterization, and Oxidation of New POCNimine-Type Pincer Complexes of Nickel Organometallics 33 5990; (g) Smith J B and Miller A J M 2015 Connecting Neutral and Cationic Pathways in Nickel-Catalyzed Insertion of Benzaldehyde into a C-H Bond of Acetonitrile Organometallics 344669

9. (a) Ozerov O V, Guo C, Fan L and Foxman B M 2004 Oxidative Addition of N-C and N-H Bonds to Zerovalent Nickel, Palladium, and Platinum Organometallics 23 5573; (b) Melaimi M, Thoumazet C, Ricard L and Floch P L 2004 Syntheses of a 2,6-bis- (methylphospholyl)pyridine ligand and its cationic Pd(II) and Ni(II) complexes - application in the palladium-catalyzed synthesis of arylboronic esters J. Organomet. Chem. 689 2988; (c) Liang L -C, Chien P -S and Huang Y -L 2006 Intermolecular Arene C-H Activation by Nickel(II) J. Am. Chem. Soc. 128 15562; (d) Liang L-C, Chien P -S and Lee P -Y 2008 Phosphorus and Olefin Substituent Effects on the Insertion Chemistry of Nickel(II) Hydride Complexes Containing Amido Diphosphine Ligands Organometallics 27 3082; (e) Sun K, Wang L and Wang Z -X 2008 Synthesis and Characterization of Amido Pincer Complexes of Lithium and Nickel 
and Catalysis of the Nickel Complexes in the Kumada Cross-Coupling Organometallics 27 5649; (f) Adhikari D, Mossin S, Basuli F, Huffman J C, Szilagyi R K, Meyer K and Mindiola D J 2008 Structural, Spectroscopic, and Theoretical Elucidation of a Redox-Active Pincer-Type Ancillary Applied in Catalysis J. Am. Chem. Soc. 130 3676; (g) Kundu S, Brennessel W W and Jones W D 2011 Synthesis and Reactivity of New Ni, Pd, and Pt 2,6-Bis(di-tert- butylphosphinito)pyridine Pincer Complexes Inorg. Chem. 50 9443; (h) Kumar S, Mani G, Mondal S and Chattaraj P K 2012 Pyrrole-Based New Diphosphines: Pd and Ni Complexes Bearing the PNP Pincer Ligand Inorg. Chem. 51 12527; (i) Vasudevan K V, Scott B L and Hanson S K 2012 Alkene Hydrogenation Catalyzed by Nickel Hydride Complexes of an Aliphatic PNP Pincer Ligand Eur. J. Inorg. Chem. 2012 4898; (j) Venkanna G T, Tammineni S, Arman H D and Tonzetich Z J 2013 Synthesis, Characterization, and Catalytic Activity of Nickel(II) Alkyl Complexes Supported by Pyrrole-Diphosphine Ligands Organometallics 32 4656; (k) Schneck F, Finger M, Tromp M and Schneider S 2016 Chemical Non-Innocence of an Aliphatic PNP Pincer Ligand Chem. - Eur. J. 2333.

10. (a) Baldovino-Pantaleón O, Hernández-Ortega $\mathrm{S}$ and Morales-Morales D 2005 Thiolation of iodobenzene catalyzed by fluorinated bis-imino nickel NNN pincer complexes Inorg. Chem. Commun. 8 955; (b) Vechorkin O, Proust V and Hu X 2009 Functional Group Tolerant Kumada-Corriu-Tamao Coupling of Nonactivated Alkyl Halides with Aryl and Heteroaryl Nucleophiles: Catalysis by a Nickel Pincer Complex Permits the Coupling of Functionalized Grignard Reagents J. Am. Chem. Soc. 131 9756; (c) Lin X, Sun J, Xi Y and Lin D 2011 How Racemic Secondary Alkyl Electrophiles Proceed to Enantioselective Products in Negishi Cross-Coupling Reactions Organometallics 30 3284; (d) Breitenfeld J, Scopelliti R and Hu X 2012 Synthesis, Reactivity, and Catalytic Application of a Nickel Pincer Hydride Complex Organometallics 31 2128; (e) Breitenfeld J, Wodrich M D and Hu X 2014 Bimetallic Oxidative Addition in Nickel-Catalyzed Alkyl-Aryl Kumada Coupling Reactions Organometallics 33 5708; (f) Pérez García P M, Ren P, Scopelliti R and Hu X 2015 Nickel-Catalyzed Direct Alkylation of Terminal Alkynes at Room Temperature: A Hemilabile Pincer Ligand Enhances Catalytic Activity ACS Catal. 5 1164; (g) Patel U N, Pandey D K, Gonnade R G and Punji B 2016 Synthesis of QuinolineBased NNN-Pincer Nickel(II) Complexes: A Robust and Improved Catalyst System for C-H Bond Alkylation of Azoles with Alkyl Halides Organometallics 35 1785; (h) Wenz J, Kochan A, Wadepohl H and Gade L H 2017 A Readily Accessible Chiral NNN Pincer Ligand with a Pyrrole Backbone and Its Ni(II) Chemistry: Syntheses, Structural Chemistry, and Bond Activations Inorg. Chem. 563631

11. (a) Castonguay A, Sui-Seng C, Zargarian D and Beauchamp A L 2006 Syntheses and Reactivities of New $\mathrm{PC}_{\mathrm{sp} 3}$ P Pincer Complexes of Nickel Organometallics 25 602; (b) Castonguay A, Beauchamp A L and Zargarian D 2008 Preparation and Reactivities of PCP-Type Pincer Complexes of Nickel Impact of Different Ligand Skeletons and Phosphine Substituents Organometallics 27
5723; (c) Castonguay A, Beauchamp A L and Zargarian D 2009 New Derivatives of PCP-Type Pincer Complexes of Nickel Inorg. Chem. 483177

12. (a) Hao J, Mougang-Soumé B, Vabre B and Zargarian D 2014 On the Stability of a POC $_{s p 3}$ OP-Type Pincer Ligand in Nickel(II) Complexes Angew. Chem. Int. Ed. 53 3218; (b) Hao J, Vabre B, Mougang-Soumé B and Zargarian D 2014 Small Molecule Activation by POC $_{\text {sp3 }}$ OP-Nickel Complexes Chem. - Eur. J. 2012544

13. (a) Castonguay A, Spasyuk D M, Madern N, Beauchamp A L and Zargarian D 2009 Regioselective Hydroamination of Acrylonitrile Catalyzed by Cationic Pincer Complexes of Nickel(II) Organometallics 28 2134; (b) Chakraborty S, Krause J A and Guan H 2009 Hydrosilylation of Aldehydes and Ketones Catalyzed by Nickel PCP-Pincer Hydride Complexes Organometallics 28 582; (c) Chakraborty S, Zhang J, Krause J A and Guan H 2010 An Efficient Nickel Catalyst for the Reduction of Carbon Dioxide with a Borane J. Am. Chem. Soc. 132 8872; (d) Chakraborty S, Patel Y J, Krause J A and Guan H 2013 A Robust Nickel Catalyst for Cyanomethylation of Aldehydes: Activation of Acetonitrile under Base-Free Conditions Angew. Chem. Int. Ed. 52 7523; (e) Lapointe S, Vabre B and Zargarian D 2015 POCOP-Type Pincer Complexes of Nickel: Synthesis, Characterization, and Ligand Exchange Reactivities of New Cationic Acetonitrile Adducts Organometallics 343520

14. (a) Zhang Y, Song G, Ma G, Zhao J, Pan C -L and Li X 2009 1,3-Dinitrone Pincer Complexes of Palladium and Nickel: Synthesis, Structural Characterizations, and Catalysis Organometallics 28 3233; (b) Kuroda J -i, Inamoto K, Hiroya K and Doi T 2009 N- Heterocyclic Carbene Derived Nickel-Pincer Complexes: Efficient and Applicable Catalysts for SuzukiMiyaura Coupling Reactions of Aryl/Alkenyl Tosylates and Mesylates Eur. J. Org. Chem. 2009 2251; (c) Inamoto K, Kuroda J -i, Kwon E, Hiroya K and Doi T 2009 Pincer-type bis(carbene)-derived complexes of nickel(II): Synthesis, structure, and catalytic activity $J$. Organomet. Chem. 694 389; (d) Liu N and Wang Z -X 2011 Kumada Coupling of Aryl, Heteroaryl, and Vinyl Chlorides Catalyzed by Amido Pincer Nickel Complexes J. Org. Chem. 76 10031; (e) Sgro M J and Stephan D W 2012 Oxidative Addition Reactions of BisAminophosphine and Bis-Phosphinite Nickel(0) Pincer Complexes Organometallics $\mathbf{3 1} 1584$

15. Naghipour A, Sabounchei S J, Morales-Morales D, Canseco-González D and Jensen C M 2007 A highly active two six-membered phosphinite palladium PCP pincer complex $\left[\mathrm{PdCl}\left\{\mathrm{C}_{6} \mathrm{H}_{3}\left(\mathrm{CH}_{2} \mathrm{OP}^{i} \mathrm{Pr}\right)_{2}-2,6\right\}\right]$ Polyhedron 261445

16. (a) Soni V, Jagtap R A, Gonnade R G and Punji B 2016 Unified Strategy for Nickel- Catalyzed C-2 Alkylation of Indoles through Chelation Assistance ACS Catal. 65666 ; (b) Jagtap R A, Soni V and Punji B 2017 Expeditious and Solvent-Free Nickel-Catalyzed C-H Arylation of Arenes and Indoles ChemSusChem 10 2242; (c) Soni V, Khake S M and Punji B 2017 Nickel-Catalyzed C( $\left.\mathrm{sp}^{2}\right)_{-}$ $\mathrm{H} / \mathrm{C}\left(\mathrm{sp}^{3}\right)-\mathrm{H}$ Oxidative Coupling of Indoles with Toluene Derivatives ACS Catal. 74202

17. APEX2, SAINT and SADABS 2006 Bruker AXS Inc Madison, Wisconsin, USA 
18. Sheldrick G M 2008 A Short History of SHELX Acta Crystallogr. A64 112

19. Farrugia L J 1997 ORTEP-3 for Windows - a version of ORTEP-III with a Graphical User Interface (GUI) $J$. Appl. Cryst. 30565

20. Pandarus V and Zargarian D 2007 New pincertype diphosphinito (POCOP) complexes of $\mathrm{Ni}^{H I}$ and

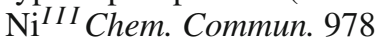

21. (a) Dondoni A and Merino P 1996 In Comprehensive Heterocyclic Chemistry II Vol. 3 Alan R Katritzky, Charles W Rees and Eric F V Scriven (Eds.) pp. 373474; (b) Okamoto K, Eger B T, Nishino T, Kondo S, Pai E F and Nishino T 2003 An Extremely Potent Inhibitor of Xanthine Oxidoreductase: Crystal structure of the enzyme-inhibitor complex and mechanism of inhibition J. Biol. Chem. 278 1848; (c) Biancalana M and Koide S 2010 Molecular mechanism of Thioflavin-T binding to amyloid fibrils Biochim. Biophys. Acta 1804 1405; (d)
Prindle A, Liu J, Asally M, Ly S, Garcia-Ojalvo J and Suel G M 2015 Ion channels enable electrical communication in bacterial communities Nature $\mathbf{5 2 7} 59$

22. (a) Ackermann L 2010 Metal-catalyzed direct alkylations of (hetero)arenes via $\mathrm{C}-\mathrm{H}$ bond cleavages with unactivated alkyl halides Chem. Commun. 46 4866; (b) Hu X 2011 Nickel- catalyzed cross coupling of nonactivated alkyl halides: a mechanistic perspective Chem. Sci. 2 1867; (c) Hirano K and Miura M 2011 Direct Carbon-Hydrogen Bond Functionalization of Heterocyclic Compounds Synlett 2011294

23. (a) Vechorkin O, Proust V and $\mathrm{Hu}$ X 2010 The Nickel/Copper-Catalyzed Direct Alkylation of Heterocyclic C-H Bonds Angew. Chem. Int. Ed. 49 3061; (b) Ackermann L, Punji B and Song W 2011 User-Friendly [(Diglyme) $\left.\mathrm{NiBr}_{2}\right]$-Catalyzed Direct Alkylations of Heteroarenes with Unactivated Alkyl Halides through C-H Bond Cleavages Adv. Synth. Catal. 3533325 